\title{
Antioxidant and Antibacterial Effect of Vitis labrusca, Vitis vinifera and Vitis vinifera Seeds Extract
}

\author{
Sakina S. Saadwi ${ }^{1 *}$, Amal Ammar ${ }^{2}$, Riham J. Kushaiba ${ }^{1}$, Surror A. Harakat ${ }^{1}$, Khairi A. Alennabi $^{3}$ \\ ${ }^{1}$ Department of Pharmacognosy, Faculty of Pharmacy, Tripoli University, Tripoli, Libya \\ ${ }^{2}$ Department of Pharmaceutical Chemistry, Faculty of Pharmacy, Univercity of Tripoli, Tripoli, Libya \\ ${ }^{3}$ Biotechnology Research center, Tripoli, Libya
}

\section{*Corresponding Author}

Sakina S. Saadwi

\author{
Article History \\ Received: 27.02.2021 \\ Accepted: 02.04.2021 \\ Published: 09.04.2021
}

\begin{abstract}
Grape seeds extract has therapeutic values including antimicrobial activity, antioxidant effect, wound healing and prevention of cardiovascular diseases. This study aimed to evaluate and compare antibacterial activity of different species of grape seed) Vitis labrusca, Vitis vinifera and Vitis vinifera) against some bacterial strains (Staphylococcus aureus, Streptococcus pneumonia, Acinetobacter Calcoaceticus, Klebsiella pneumoniae and Escherichia coli). Determine antioxidant effect of grape seed extracts (qualitatively). Antibacterial effects was performed using agar cup cut diffusion method for all bacterial species, followed by using minimum inhibitory concentration MIC for the species showed to be inhibited by grape seeds extracts. Antioxidant assay was done using DPPH scavenging test, methanolic solution of each grape seeds was spotted on TLC paper, sprayed with $0.2 \%$ methanolic solution of diphenyl picryl hydrazyl (DPPH) reagent. Vitamin C was used as positive control. From the results, all grape species didn't have any effect on K. pneumonia and E. coli, red and black grape seeds showed the highest inhibition zone (20 mm) on Staph. Aureus agar plate, green grape had the highest effect on Sterp. Pneumonia agar plate $(20 \mathrm{~mm})$. The lowest effect was for the red grape seeds extract $(13 \mathrm{~mm})$ on Acinetobacter calciaceticus. In general the three grape seeds extract had effect on Staph. aureus, Sterp. pneumonia and Acinetobacter calciaceticus. The red and black grape seed extract was effective against Sterp. pneumonia strain at MIC values of $7.8 \mathrm{mg} / \mathrm{mL}$ and black grape seeds extract had MIC at $7.8 \mathrm{mg} / \mathrm{mL}$ on Staph. aureus. However, the test for MIC of seeds extracts for the rest of bacterial species ranged between 15.62 and 87.5 $\mathrm{mg} / \mathrm{mL}$. The result showed that black grape seeds extract had the largest spot change in color indicating strong antioxidant effect. The lowest effect was by red grape seeds. From this result black grape showed to be the best grape seeds extract among the three chosen species in its antibacterial and antioxidant efficacy.
\end{abstract}

Keywords: Staphylococcus aureus, Streptococcus pneumonia, Acinetobacter Calcoaceticus, Klebsiella pneumoniae and Escherichia coli, Grape seeds and DPPH.

\section{INTRODUCTION}

Grape seed extract is can be found as a dietary supplement in a liquid form, tablets or capsules. It's generally containing 50 to $100 \mathrm{mg}$ of the extract [1]. Grape seed consist of vitamins, minerals, lipid, protein, carbohydrates and 5$8 \%$ polyphenols. The most abundant phenolic compounds isolated from grape seeds are catechin, epicatechin, and procyanidins in addition to dimmers and trimmers [2]. Grape seed proanthocyanidins constitute a complex mixture that consisted of procyanidins and procyanidin gallates [3]. The polyphenols of grape seeds have been known for their advantageous role in human health. The grape seed is shown to exhibit therapeutic values such as antioxidant, antiinflammatory, anti-bacterial, anti-cancer, antiviral, cardioprotective, hepatoprotective, neuroprotective, antiaging and anti-diabetic. The oil extracted from grape seeds is used in cosmetic, culinary, pharmaceutical and medical purposes [49]. The polyphenolic fractions and gallic acid derivatives are reported to have antibacterial activity [10], Grape seed proanthocyanidins have been reported to have potent antioxidant effect [11]. Extract of grape seed which were obtained from grapes cultivated in Hasandede, Emir and Kalecik Karasi wine cultivars in Turkey showed concentrations of $2.5 \%$ $5 \%$ exhibited the most inhibitory effect against a variety of microorganisms including E. coli, K. pneumoniae, and $S$.

Copyright (C) 2021 The Author(s): This is an open-access article distributed under the terms of the Creative Commons Attribution 4.0 International License (CC BY-NC 4.0) which permits unrestricted use, distribution, and reproduction in any medium for non-commercial use provided the original author and source are credited. 
aureus [12]. A similar grape seed extract was tested against 21 gram positive strains and gram negative cocci and showed that gram positive cocci are more susceptible, especially S. aureus [13]. Complete inhibition of 43 clinical strains of Methicillin resistant $S$. aureus was noted at concentration of $3 \mathrm{mg} / \mathrm{mL}$ crude grape seed extract [14]. In other study performed on grape pomace (skin and seed) which produced during wine production and considered as a waste product of wine industries, antimicrobial activity of grape seed extract (GSE) was determined using agar well diffusion method. It was conducted to determine inhibitory effect of GSE against Staphylococcus aureus, Escherichia coli and Klebsiella pneumonia isolated from urinary tract infection. S. aureus and E. coli was inhibited to high and least extent respectively by GSE. GSE can be used in the treatment of urinary tract infections [15]. Another study tested the antioxidant activity of grape seed extracts using $\beta$-carotene-linoleate model system and linoleic acid peroxidation method. The results showed that different extracts had 65\%-90\% (scavenging rate) antioxidant activity at $100 \mathrm{ppm}$ concentration, indicating that grape seed extracts might be used as preservation of food products as well as for health supplements and nutraceuticals [16]. The present study aimed to determined antimicrobial activity of three spp. of grape seed extracts (GSE) against chosen bacteria in addition to the qualitative antioxidant effect.

\section{MATERIALS ANd Methods}

\section{Collection and Preparation of Grape Seed Extract (GSE)}

Fresh grape fruits (Vitis labrusca or red, Vitis vinifera or black and Vitis vinifera or Green grape) were collected in the time between Augusts and October 2019. Seeds of black and green grape were collected house garden in Tripoli, while seeds of red grape were collected from local Libyan market. All seeds were manually separated and collected from its fruits, dried in oven at temperature of $50 \mathrm{C}^{\mathrm{o}}$ (Figure 1). Grape seeds were weighed continuously until weight is fixed. The dried grape seeds were grinded to powder, weighed, labeled and kept in dry place.

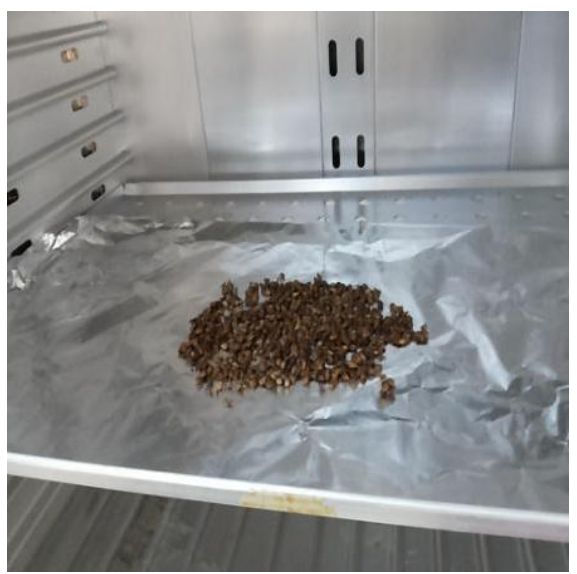

Fig-1: Grape seed drying in oven at $50 \mathrm{C}^{\circ}$

Dried seed samples were extracted by cold maceration (Figure 2). Known weights of grape seeds powder were macerated in methanol in a closed container tank and left for $72 \mathrm{hrs}$ x 3 with stirring from time to time. Methanolic seeds extract was filtered using filter paper. All extracts were concentrated using rotary evaporator at $64-65.5 \mathrm{C}^{\circ}, 150 \mathrm{rpm}$ to obtain the crude extract.

Percentage of yield of all extracts was calculated using this formula:

$\%$ of yield $=($ weight of crude extract $/$ weight of original plant powder $) \times 100$

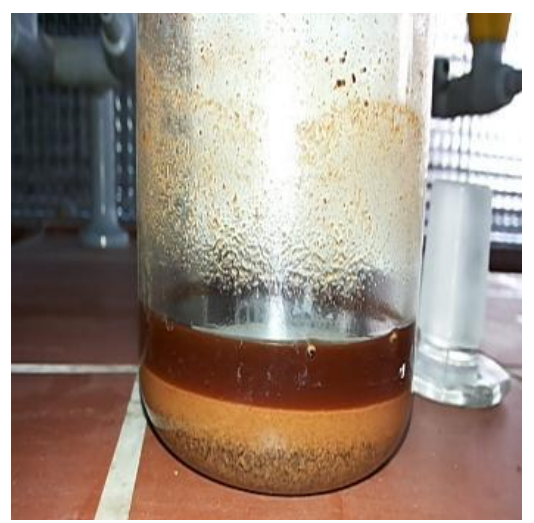

Fig-2: Grape seeds cold maceration 


\section{Antibacterial activity of GSE}

Grape seeds crude extracts were tested for their antibacterial activities against Staphylococcus aureus, Streptococcus pneumonia, Acinetobacter Calcoaceticus, Klebsiella pneumoniae and Escherichia coli. Bacterial strains were obtained from the bacterial stock, Department of Microbiology, faculty of pharmacy, Tripoli University and respiratory disease hospital. Agar cup cut diffusion method was used for all bacterial species, followed by determination of minimum inhibitory concentration (MIC) for strains that were inhibited by grape seeds extracts. Bacterial suspensions were cultured in nutrient broth for $24 \mathrm{hrs}$, stocked on agar plate by cotton swab. Cuts were made on agar surface. One gram of each seeds extract was weight and dissolved in $1 \mathrm{ml}$ of distilled water, then $100 \mu$ of extract was poured in agar cup cuts and the plates were incubated at $37 \mathrm{C}^{\circ}$ for $24 \mathrm{hrs}$. Diameter around cup cuts with no bacterial growth was measured and recorded. MIC test was applied for bacteria with the highest diameters produced by plant seeds extracts

\section{Minimum Inhibitory Concentration test (MIC)}

A series of broths are mixed with 2 fold serially diluted antibiotic (Cephalexin) solutions and a standard inoculum is applied (Figure 3). After incubation, the minimum inhibitory concentration MIC was determined as the first broth in which growth of the organism has been inhibited. The more resistant an organism the higher MIC will be. $1 \mathrm{ml}$ of each bacterial strain equal to $108 \mathrm{cfu}$ per $\mathrm{ml}$ was transferred into set of six test tubes and $1 \mathrm{ml}$ of plant extracts was added, then two-folds dilution has been made to obtain a concentration range of $500 \mathrm{mg} / \mathrm{ml}$ to $6.25 \mathrm{mg} / \mathrm{ml}$. after $18 \mathrm{hr}$ of incubation at $37 \mathrm{C}^{\circ}, 0.1 \mathrm{ml}$ of each concentration were inculcated on to MHA agar using the streak plate method. The plates were then incubated at $37^{\circ} \mathrm{C}$ for 24 hours. The least concentration that did not show growth of the test was recorded.

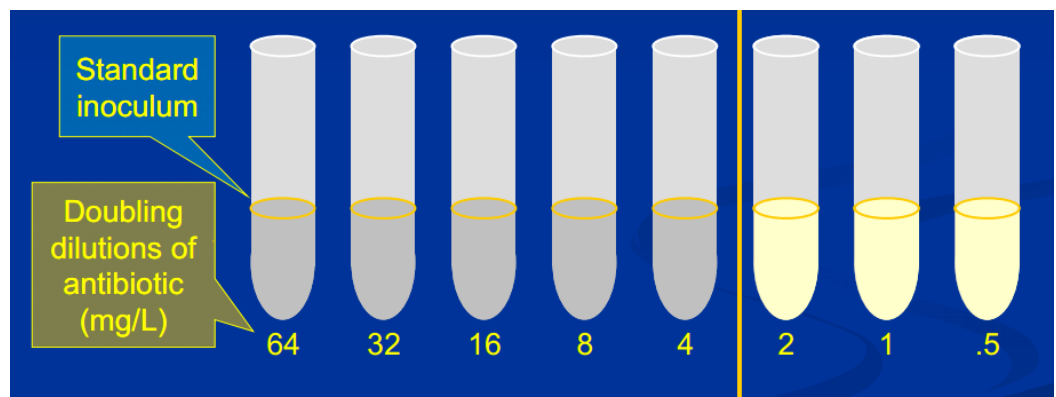

Fig-3: Minimum inhibitory concentration (MIC) procedure for grape seeds extracts

\section{Antioxidant (DPPH) scavenging activity}

Methanolic solution of each grape seeds was spotted on TLC plate, left to dry eluted by suitable solvent system and sprayed with $0.2 \%$ methanolic solution of diphenyl picryl hydrazyl (DPPH) reagent. Change in color from violet to yellow considered as a positive result. Vitamin $\mathrm{C}$ was used as positive control.

\section{RESUltS AND DiscuSSION}

All grape seeds samples were extracted by cold maceration for $72 * 3$, filtrated and concentrated. The percentage of yield was calculated (table 1) for all spices samples using this formula:

$\%$ Percentage of yield $=($ weight of crude extract $/$ weight of original powder $) \times 100$

Table-1: Percentage of yield of the three species of grape seeds

\begin{tabular}{|c|c|}
\hline Grape seeds samples & \% of yield of grape Seeds \\
\hline Red grape & $12.9 \%$ \\
\hline Green grape & $11.3 \%$ \\
\hline Black grape & $8.2 \%$ \\
\hline
\end{tabular}

As shown in the above table, red grape seeds percentage of yield were higher than the percentage of yield of other two grape species, although there was no big difference in the $\%$ of yield of the three species.

\section{Antibacterial activity of GSE}

Grape seeds crude extracts were tested for their antibacterial activities. The results in table 2 showed that all grape seed extracts didn't have any effect on $K$. pneumonia and E. coli, red and black grape seeds showed the highest inhibition zone $(20 \mathrm{~mm})$ on Staph. Aureus agar plate, green grape had the highest effect on Sterp. Pneumonia agar plate $(20 \mathrm{~mm})$. The lowest effect was for the red grape seeds extract $(13 \mathrm{~mm})$ on Acinetobacter calciaceticus. In general the three grape seed extracts had effect on Staph. aureus, Sterp. pneumonia, and Acinetobacter calciaceticus. 
Table-2: Antibacterial effect of three grape seed extracts against different bacterial species

\begin{tabular}{|c|c|c|c|c|c|}
\hline Extract 500mg/ml & $\begin{array}{c}\text { Staph. } \\
\text { aureus }(\mathbf{m m})\end{array}$ & $\begin{array}{c}\text { Sterp. } \\
\text { pneumonia } \\
(\mathbf{m m})\end{array}$ & $\begin{array}{c}\text { Acinetobacter } \\
\text { calciaceticus } \\
(\mathbf{m m})\end{array}$ & $\begin{array}{c}\text { K. } \\
\text { pneumonia } \\
(\mathbf{m m})\end{array}$ & E. coli $(\mathbf{m m})$ \\
\hline Red grape seeds extract & $\mathbf{2 0} \pm 0.9$ & $18 \pm 0.6$ & $13 \pm 0.8$ & $-\mathrm{Ve}$ & $-\mathrm{Ve}$ \\
\hline Black grape seeds extract & $\mathbf{2 0} \pm 0.6$ & $18 \pm 0.4$ & $14 \pm 0.5$ & $-\mathrm{Ve}$ & $-\mathrm{Ve}$ \\
\hline Green grape seeds extract & $15 \pm 0.3$ & $\mathbf{2 0} \pm 0.9$ & $15 \pm 0.5$ & $-\mathrm{Ve}$ & $-\mathrm{Ve}$ \\
\hline \multicolumn{7}{|c|}{ Cephalexin } & $-\mathrm{Ve}$ & $-\mathrm{Ve}$ & $-\mathrm{Ve}$ & $-\mathrm{Ve}$ & $-\mathrm{Ve}$ \\
\hline \multicolumn{6}{|c}{ All values are expressed as mean $\pm \mathrm{SD}$} \\
\hline
\end{tabular}

As the above mentioned results showed, the three grape seeds extracts exhibited antibacterial effect on the chosen strains. This might be explained due to the presence of phenolic compound in grape seeds.

\section{Minimum Inhibitory Concentration test results (MIC)}

MIC test was performed on the micro-organisms which were susceptible to the effects of the grape seed extract, namely Staph. aureus, Sterp. pneumonia and Acinetobacter calciaceticus. This test was performed to measure the lowest concentration of a reagent that inhibits the visible growth of test microbes (MIC) (Table 3). The red and black grape seed extract was effective against Sterp. pneumonia strain at MIC values of $7.8 \mathrm{mg} / \mathrm{mL}$ and black grape seeds extract had MIC at $7.8 \mathrm{mg} / \mathrm{mL}$ on Staph. aureus. However, the test for MIC of seeds extracts for the rest of bacterial species ranged between 15.62 and $87.5 \mathrm{mg} / \mathrm{mL}$.

Table-3: Minimum inhibitory concentration MIC of three grape species on different bacterial strains

\begin{tabular}{|c|c|c|c|}
\hline Bacterial species & $\begin{array}{c}\text { Vitis labrusca (Red) } \\
\mathrm{mg} / \mathrm{ml}\end{array}$ & $\begin{array}{c}\text { Vitis vinifera (Black) } \\
\mathrm{mg} / \mathrm{ml}\end{array}$ & $\begin{array}{c}\text { Vitis vinifera } \\
\text { (Green) } \mathrm{mg} / \mathrm{ml}\end{array}$ \\
\hline Acinetobacter cacoaceticus & $62.5 \pm 1.2$ & $31.25 \pm 1.3$ & $31.25 \pm 0.8$ \\
\hline Sterp. pneumonia & $7.8 \pm 1.5$ & $\mathbf{7 . 8} \pm 0.9$ & $31.25 \pm 1.2$ \\
\hline Staph. aureus & $15.62 \pm 0.9$ & $\mathbf{7 . 8} \pm 1.0$ & $87.5 \pm 1.6$ \\
\hline \multicolumn{4}{|c|}{ All values are expressed as mean \pm SD } \\
\hline
\end{tabular}

As the tables 2 and 3 showed, grape seeds extract had antibacterial effect on most of the chosen strains. This might be due to the phenolic contents found in grape seed which are partially hydrophobic, and are considered to interact with the bacterial cell wall and lipopolysaccharide interfaces by decreasing membrane stability. The amount of phenolic content in grape seed extract has been directly correlated to the antibacterial properties [17, 18]. Antibacterial activity of grape seed extract is attributed to its content of Stigmasterol, which cause bacterial components degradation by surface interaction and pore formation in the cell wall of bacteria. It might also be accounted to the presence of tannins that has the ability to inactive microbial adhesions, enzymes and cell envelope transport proteins, their complexity with polysaccharide and their ability to modify the morphology of microorganisms [19]. Therefore, this observation is suggestive of the antibacterial effect of grape seed extract. In our study, grape seed extract proved to be bactericidal and was able to produce zones of inhibition ranging from 13-20 mm against chosen bacterial strains with the concentrations of the extract ranging from $15.62 \mathrm{mg} / \mathrm{mL}$ and $87.5 \mathrm{mg} / \mathrm{mL}$. Red and black grape seeds extracts showed the highest inhibition zone $(20 \mathrm{~mm})$ on Staph. Aureus, green grape extract had the highest effect on Sterp. Pneumonia (20 mm).

Reagor L et al. carried out a study to determine the effectiveness of processed grape fruit seed extract as an antibacterial agent against sixty seven distinct biotypes [20]. The results suggested that the antibacterial characteristic of grape seed extract is comparable to that of proven topical antibacterials. One study reported that the structure- activity correlation assays showed that the hydroxyl group of the phenolic compound was effective against E.coli and the benzene ring was effective against $S$. aureus [21]. According to Al-Habeb A and Al-Saleh E et al. the antibacterial effect of grape seed extract against MRSA is due to disruption of bacterial cell wall membrane in scanning and transmission electron microscopy which could be accounted to the presence of potent polyphenolics in grape seed extract [14].

\section{Antioxidant (DPPH) scavenging activity test results}

The result showed that black grape seeds extract had the largest spot change in color. The lowest effect was by red grape seeds (figure 4). 


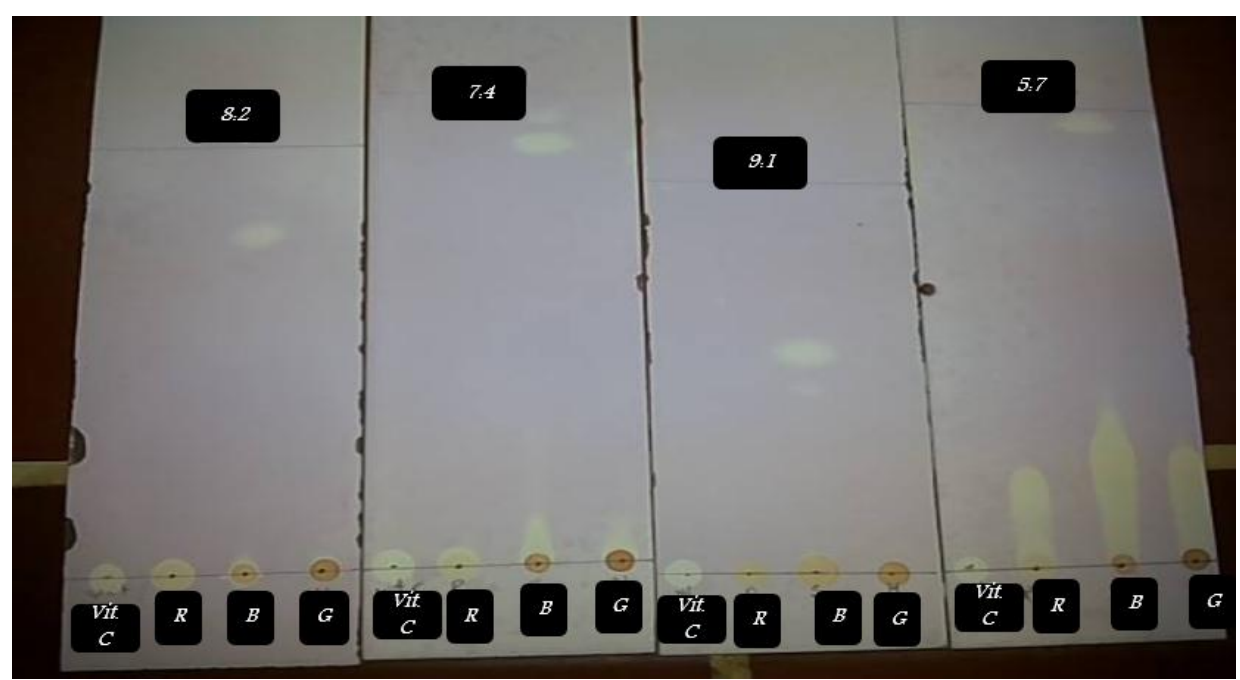

Fig-4: DPPH scavenging activity test of three grape species on TLC in different solvent system, Vit C was used as +ve control. $\mathbf{R}=$ Red, $\mathbf{B}=$ black, $\mathbf{G}=$ Green

As the above figure showed, all grape seeds extracts exhibited a change in DPPH color indicating antioxidant properties. This had been studied extensively by many researchers. Antioxidants such as flavonoids, which act as free radical quenchers [22]. Phenolic compounds from grape seeds have pharmacological and nutraceutical benefits showing antiviral and antimutagenic actions [23] that are closely related to their antioxidant and singlet oxygen quenching ability. Recognition of such health benefits of catechins and procyanidins has led to the use of grape seed extract as a dietary supplement $[24,25]$. Besides its antioxidant activity, the grape seed extract proved to act also as antibacterial agent [26, 27].

\section{CONCLUSION}

In this study, different grape seeds species were extracted by cold maceration and tested on antibacterial effects on different bacterial strains using cup-cut agar diffusion method and MIC method, in addition to its antioxidant activity using DPPH scavenging activity test, red grape (Vitis labrusca) gave the highest percentage of yield (12.9\%) compared to the other two tested grape species. While black grape resulted in the lowest percentage of yield (8.3\%). Black Grape showed to be the most effecting as DPPH scavenger compared to the other two tested species, while the lowest effect was by red grape seeds. In general the three tested grape extracts showed to be effective against Staph. aureus, Sterp. pneumonia and Acinetobacter, while they had no effect on $K$. pneumonia and $E$. Coli. The result of MIC test showed that black grape had the best effect against Staph. aureus, Sterp. Arugenosa $(7.8 \mathrm{mg} / \mathrm{ml})$. finally, black grape extract was the best among the three chosen species in its antibacterial and antioxidant efficacy.

\section{REFERENCES}

1. MNT. (2015). What is grape seed extract? What are the benefits of grape seed extract? http://www.medicalnewstoday.com/articles/263332.php. Viewed on May 2015. 22

2. Shi, J., Yu, J., Pohorly, J. E., \& Kakuda, Y. (2003). Polyphenolics in grape seeds-biochemistry and functionality. Journal of Medicinal Food, 6(4), 291-299.

3. Hayasaka, Y., Waters, E. J., Cheynier, V., Herderich, M. J., \& Vidal, S. (2003). Characterization of proanthocyanidins in grape seeds using electrospray mass spectrometry. Rapid Communications in Mass Spectrometry, 17(1), 9-16.

4. Baydar, N. G., Özkan, G., \& Çetin, E.S. (2007). Characterization of grape seed and pomace oil extracts. Grasas $Y$ Aceites, 58(1), 29-33.

5. Li, H., Wang, X., Li, P., Li, Y., \& Wang, H. (2008). Comparative study of antioxidant activity of grape (Vitis vinifera) seed powder assessed by different methods. Journal of Food and Drug Analysis, 16(6), 1-7.

6. Suwannaphet, W., Meeprom, A., Yibchok-Anun, S., \& Adisakwattana, S. (2010). Preventive effect of grape seed extract against high-fructose diet-induced insulin resistance and oxidative stress in rats. Food and Chemical Toxicology, 48(7), 1853-1857.

7. Canbay, H. S., \& Bardakçı, B. (2011). Determination of fatty acid, C, H, N and trace element composition in grape seed by GC/MS, FTIR, elemental analyzer and ICP/OES. SDU. Journal of Science (E-Journal), 6(2), 140-148.

8. Su, X., \& D'Souza, D. H. (2011). Grape seed extract for control of human enteric viruses. Applied and Environmental Microbiology, 77(12), 3982-3987. 
9. Mendes, J. A. S., Prozil, S. O., Evtuguin, D. V., \& Lopes, L., P., C. (2013). Towards comprehensive utilization of winemaking residues: Characterization of grape skins from red grape pomaces of variety Touriga Nacional. Industrial Crops and Products, 43(1), 25-32.

10. Ashok Kumar, K., \& Vijayalakshmi, K. (2011). GC-MS Analysis of phytochemical constituent inEthanolic extracts of Punicagranatum peel and Vitisvinifera seeds. Int J Pharma Bio sci, 2(4), 461-468.

11. Sen, C. K., \& Bagchi, D. (2001). Regulation of inducible adhesion molecule expression in human endothelial cells by grape seed proanthocyanidin extract. Mol Cell Biochem, 216(1-2), 1-7.

12. Baydar, N. G., Sagdic, O., Ozkan, G., \& Cetin, S. (2006). Determination of antibacterial effects and total phenolic contents of grape (Vitis vinifera L.) seed extracts. Int J Food Sci Technol, 41(7), 799-804.

13. Kao, T. T., Tu, H. C., Chang, W. N., Chen, B. H., Shi, Y. Y., \& Chang, T. C. (2010). Grape seed extract inhibits the growth and pathogenicity of Staphylococcus aureus by interfering with dihydrofolate reductase activity and folatemediated one-carbon metabolism. Int J Food Microbiol, 141(1-2), 17-27.

14. Al-Habib, A., Al-Saleh, E., Safer, A. M., \& Afzal, M. (2010). Bactericidal effect of grape seed extract on methicillin-resistant Staphylococcus aureus (MRSA). J Toxicol Sci, 35(3), 357-364.

15. Ranjitha, C. Y., Priyanka, S., Deepika, R., Smitha Rani, G. P., Sahana, J., \& Prashith Kekuda, T. R. (2014). Antimicrobial activity of grape seed extract. World Journal of Pharmacy and Pharmaceutical Sciences, 3(8), 14831488 .

16. Jayaprakasha, G. K., Singh, R. P., \& Sakariah, K. K. (2001). Antioxidant activity of grape seed (Vitis vinifera) extracts on peroxidation models in vitro. Food Chem, 73(3), 285-290.

17. Baydar, N. G., Sagdic, O., Ozkan, G. \& Cetin, S. (2006). Determination of antibacterial effects and total phenolic contents of grape (Vitis vinifera L.) seed extracts. International Journal of Food Science and Technology, 41(7), 799-804.

18. Jayaprakasha, G. K., Selvi, T., \& Sakariah, K. K. (2003). Antibacterial and antioxidant activities of grape (Vitis vinifera) seed extracts. Food Research International, 36(2), 117-122.

19. Cowan, M. M. (1999). Plants products as antimicrobial agents. Clin Microbio Rev, 12(4), 564-82.

20. Raegor, L., Gusman, K., McCoy, L., Carino, E., \& Heggers, J. P. (2002). The effectiveness of processed grapefruitseed extract asan antibacterial agent: an in vitro agar assay. J Altern Complement Med, 8(3), 325-332.

21. BinitShrestha, M. L., \& Srithavaj, T. (2012). In Vitro antimicrobial effects of grape seedextrat on periimplantitismicroflora in craniofacial implants. APJTB, 2(10), 822-825.

22. Zhou, B., Miao, Q., Yang, L. \& Liu, Z. L. (2005). Antioxidative effects of flavonols and their glycosides against the free-radical-induced peroxidation of linoleic acid in solution and in micelles. Chemistry-A European Journal, 11(2), 680-691.

23. Saito, M., Hosoyama, H., Ariga, T., Kataoka, S., \& Yamaji, N. (1998). Antiulcer activity of grape seed extract and procyanidins, Journal of Agricultural and Food Chemistry, 46(4), 1460-1464.

24. Laparra, J., Michaud, J., \& Masquelier, J. (1979). Action of oligomeric procyanidins on vitamin C deficient guinea pig. Bulletin-Société de Pharmacie de Bordeaux, 118(7), 13.

25. Soleas, G. J., Diamandis, E. P., \& Goldberg, D. M. (1997). Wine as a biological fluid: history, production, and role in disease prevention. Journal of Clinical Laboratory Analysis, 11(5), 287-313.

26. Ahn, J., Grün, I. U., \& Mustapha, A. (2007). Effects of plant extracts on microbial growth, color change, and lipid oxidation in cooked beef. Food Microbiology, 24(1), 7-14.

27. Chedea, V. S., Braicu, C., Chirilă, F., Ober, C., \& Socaciu, C. (2011). Antibacterial action of an aqueous grape seed polyphenolic extract. African Journal of Biotechnology, 10(33), 6276-6280.

CITATION: Sakina S. Saadwi et al (2021). Antioxidant and Antibacterial Effect of Vitis labrusca, Vitis vinifera and Vitis vinifera Seeds Extract. South Asian Res J Pharm Sci, 3(2): 34-39. 